\title{
SUMEge
}

International Journal of Environment and Geoinformatics (IJEGEO) is an international, multidisciplinary, peer reviewed, open access journal.

\section{Rockfall analysis based on UAV technology in Kazıklıali Gorge, Aladağlar (Taurus Mountains, Turkey)}

\section{Mustafa UTLU, Muhammed Zeynel ÖZTÜRK, Mesut ŞİMŞEK}

\author{
Chief in Editor \\ Prof. Dr. Cem Gazioğlu \\ Co-Editors \\ Prof. Dr. Dursun Zafer Şeker, Prof. Dr. Şinasi Kaya, \\ Prof. Dr. Ayşegül Tanık and Assist. Prof. Dr. Volkan Demir
}

Editorial Committee (December 2020)

\begin{abstract}
Assos. Prof. Dr. Abdullah Aksu (TR), Assit. Prof. Dr. Uğur Algancı (TR), Prof. Dr. Bedri Alpar (TR), Prof. Dr. Levent Bat (TR), Prof. Dr. Paul Bates (UK), İrşad Bayırhan (TR), Prof. Dr. Bülent Bayram (TR), Prof. Dr. Luis M. Botana (ES), Prof. Dr. Nuray Çağlar (TR), Prof. Dr. Sukanta Dash (IN), Dr. Soofia T. Elias (UK), Prof. Dr. A. Evren Erginal (TR), Assoc. Prof. Dr. Cüneyt Erenoğlu (TR), Dr. Dieter Fritsch (DE), Prof. Dr. Çiğdem Göksel (TR), Prof.Dr. Lena Halounova (CZ), Prof. Dr. Manik Kalubarme (IN), Dr. Hakan Kaya (TR), Assist. Prof. Dr. Serkan Kükrer (TR), Assoc. Prof. Dr. Maged Marghany (MY), Prof. Dr. Michael Meadows (ZA), Prof. Dr. Nebiye Musaoğlu (TR), Prof. Dr. Masafumi Nakagawa (JP), Prof. Dr. Hasan Özdemir (TR), Prof. Dr. Chryssy Potsiou (GR), Prof. Dr. Erol Sarı (TR), Prof. Dr. Maria Paradiso (IT), Prof. Dr. Petros Patias (GR), Prof. Dr. Elif Sertel (TR), Prof. Dr. Nüket Sivri (TR), Prof. Dr. Füsun Balık Şanlı (TR), Prof. Dr. Uğur Şanlı (TR), Duygu Ülker (TR), Prof. Dr. Seyfettin Taş (TR), Assoc. Prof. Dr. Ömer Suat Taşkın (US), Assist. Prof. Dr. Tuba Ünsal (US), Dr. İnese Varna (LV), Dr. Petra Visser (NL), Prof. Dr. Selma Ünlü (TR), Prof. Dr. Murat Yakar (TR), Assit. Prof. Dr. Sibel Zeki (TR)
\end{abstract}


Reaserch Article

\title{
Rockfall analysis based on UAV technology in Kazıklıali Gorge, Aladağlar (Taurus Mountains, Turkey)
}

\author{
Mustafa UTLU $^{1}$ (D), Muhammed Zeynel Öztürk² (iD), Mesut Şimşek ${ }^{3}$ \\ ${ }^{1}$ Bingöl University, Faculty of Science and Letters, Department of Geography, Bingöl, Turkey \\ ${ }^{2}$ Niğde Ömer Halis Demir University, Faculty of Science and Letters, Department of Geography, Niğde, Turkey \\ ${ }^{3}$ Mustafa Kemal University, Faculty of Science and Letters, Department of Geography, Hatay, Hatay, Turkey \\ * Corresponding author: Mustafa Utlu \\ *E-mail: utlumus@gmail.com
}

How to cite: Utlu et al., (2020). Rockfall analysis based on UAV technology in Kazıklıali Gorge, Aladağlar (Taurus Mountains, Turkey), International Journal of Environment and Geoinformatics (IJEGEO), 7(3): 239-251. DOI: 10.30897/ijegeo.740963

\begin{abstract}
Rockfall is one of the most dangerous hazards in mountainous and hilly areas. In this study, rockfall characteristics of the Kazıkliali Gorge $\left(0.25 \mathrm{~km}^{2}\right)$ in the lower Emli River Basin located in the SW part of the Aladağlar Mountains was investigated using unmanned air vehicle (UAV) technology and rockfall modeling. To determine rockfall properties, an orthophoto and digital surface model which have a $3 \mathrm{~cm}$ resolution were created using UAV images. Then, whole fallen blocks more than $0.5 \mathrm{~m}$ in diameter were digitized as polygons in GIS. As a result, 10,348 fallen rocks were determined in Kazlkliali Gorge. Via these polygons, density maps were created and frequency distributions were calculated. According to the spatial distribution of density, the geomorphological characteristics of the canyon affect the rockfall density. While the upper and middle parts of the canyon which are the narrowest have high density, the lower part of the valley which is the largest part has low density. The results of 3D rockfall analysis show that the maximum kinetic energy, maximum jump height and maximum velocity reaches $1400 \mathrm{~kJ}, 15 \mathrm{~m}$ and $32 \mathrm{~m} / \mathrm{s}$ on the canyon walls, respectively. The upper and middle parts of the canyon walls which correspond to high rockfall density have maximum kinetic energy, rock jump height and rock velocity.
\end{abstract}

Keywords: Rockfalls, Unmanned air vehicle (UAV), Orthophoto, Digital Elevation Model (DEM), Morphometric properties

\section{Introduction}

Landslides are geological natural disasters and they occur frequently in mountainous regions (Michoud et al. 2012; Giordan et al. 2015). Rockfall is one of the most catastrophic types of landslides (Porter and Orombelli 1981; Whalley 1984; Flageollet and Weber 1996) and they mostly depend on slope instability. Rockfalls happen when blocks become detach through the increase of crack systems in blocks of rock (Giordan et al. 2015), especially on the steep slopes of hilly mountains (Michoud et al. 2012; Giordan et al. 2015). They are mainly controlled by three types of factors, namely, 1) structural, 2) environmental and 3) anthropogenic factors (Ashfield 2001). Structural factors refer to rapidly evolving gravity and slope rate properties (Whalley 1984; Flageollet and Weber 1996; Dorren and Seijmonsbergen 2003; Strunden et al. 2015; Pellicani et al. 2016). Environmental factors are dynamic processes such as climatic parameters; for example, freeze-thaw events (McCarroll et al. 1998; Matsuoka 1999; Youssef et al. 2015), seismic activity (Bull et al. 1994; Vidrih et al. 2001; Abebe et al. 2010; Youssef et al. 2015), the roots of plants and trees which develop in the cracks of rocks, and chemical rock weathering (Hoek, 2007; Y1lmaz et al. 2008; Aydin and Eker 2017;). Anthropogenic factors include not only the exploding of mining excavations but also during the construction of roads that vibrate from vehicles so on. (Ashfield 2001; Dorren 2003; Vijayakumar et al. 2011; Cybulski 2014; Youssef et al. 2015).
Depending on the impact of blocks on a slope's stability, rockfalls can be of various size and movement types, such as rock to toppling, falling, bouncing or rolling/ sliding (Erismann and Abele 2001). Accordingly, the size of the falling rocks varies from $1 \mathrm{~m}^{3}$ to $100 \mathrm{~m}^{3}$ and the velocity ranges from $1-3 \mathrm{~m} / \mathrm{s}$ to $10 \mathrm{~m} / \mathrm{s}$ (Cruden and Varnes 1996). When we compare the movement of small pieces of rock with the overall rockfall, they are capable of rapid movement and a high degree of risk (Dietze et al. 2017). Due to their velocity, rockfalls may be extremely dangerous to the environment and human life (Parise 2002). Rockfalls may also threaten elements such as roads, settlements, transportation corridors, etc. (Binal and Ercanoğlu 2010). For these reasons, rockfalls are among the most specific geomorphic process studied in the world (Chau et al. 2003; Dorren 2003; Schneuwly and Stoffel 2008; Mineo et al. 2018). Earthquakes, landslides, floods, rockfalls and avalanches are the most common types of natural disaster in Turkey (Şahin and Altın 2016). Rockfalls occur especially in the spring and winter periods in Turkey because of precipitation and freezethaw event cycles (Karaağaç, 2019). Rockfall corresponds to between $10 \%$ and $12 \%$ percent of the total damage caused by all natural hazards in Turkey (Kutluca 2006; Binal and Ercanoğlu 2010; Aydın et al. 2012). For example, 2956 rockfall events have taken place that 1703 settlements were damaged and 19,422 people were affected in between 1950 and 2008 (Gökçe et al. 2008; Aydin et al. 2012). Therefore, rockfall is one of the most crucial topics for scientists in many areas of Turkey 
(Topal et al. 2007, 2012; Ulusay et al. 2006; Aydin 2007; Y1lmaz et al. 2008; Zorlu et al. 2008, 2011; Tunusluoglu and Zorlu 2009; Binal and Ercanoğlu 2010; Aydın et al. 2012; Keskin 2013; Zeybek and Şanlıŏlu 2014; Topal and Hatipoglu 2015; Kaya and Topal 2015; Polat et al. 2016; Taga and Zorlu 2016; Gül et al. 2016; Dinçer et al. 2016; Török et al. 2017; Geniş et al. 2017; Aydın and Eker 2017; Kayabaşı 2018; Ozturk et al. 2019). In particular, the provinces of Sivas, Erzurum, Adıyaman, Nevşehir, Niğde, Kayseri and Artvin have the highest rockfalls risk (Ergünay 2007; Gökçe et al. 2008;
Şener 2019). While most rockfall studies concentrate on urban settlements in hilly areas, rockfalls are occurring frequently on steep slopes in mountainous regions (Parise 2002). In this study, the rockfall characteristics of the Kazıklıali Gorge (Taurus Mountains; Figure 1) were investigated using unmanned air vehicle (UAV) technology and rockfall analysis software (RAMMS). Although there is no settlement in the study area, it's one of the most popular rock climbing areas in Turkey. Therefore, it is important to determine its rockfall characteristics and rockfall risk assessment.
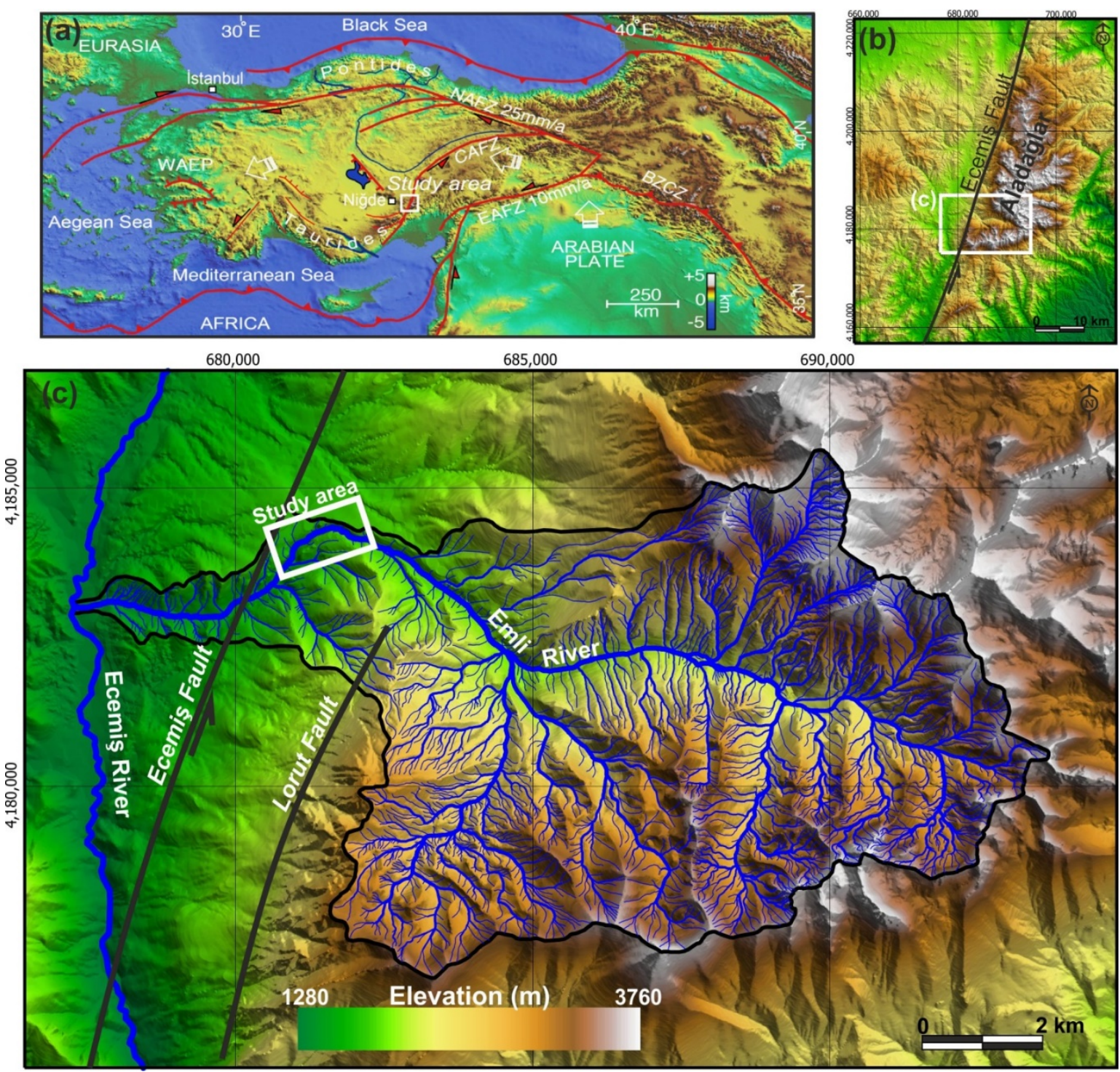

Figure 1. Location map of study area. (a) Simplified tectonic map of Turkey (Y1ldırım et al. 2011. Arrows indicate the movement of lithospheric plates. Numbers on main fault zones are observed lateral slip-rates. NAFZ: North Anatolian Fault Zone, CAFZ: Central Anatolian Fault Zone, EAFZ: East Anatolian Fault Zone, WAEP: Western Anatolia Extensional Province, BZCZ: Bitlis-Zagros Convergence Zone). (b) Digital elevation model of Aladağlar Mountains and location of Emli River basin. (c) Drainage basin of Emli River and location of KazıklıaliGorge. 


\section{Study Area}

Kazıkliali Gorge is found in the lower part of Emli River Basin located in the SW part of the Aladağlar Mts. (Figs. 1c; 2a). The Aladağlar range is a large massif and is bordered by the left- lateral Ecemiş Fault corridor (Fig. 1b). The geology of the Aladağlar is characterized by the presence of five carbonate nappes, which were thrust onto each other during the late Cretaceous period due to the closure of the northern branch of the Neo-Tethys Ocean (Özgül 1983; Tekeli et al. 1983). As a result of rapid uplifts, especially during the early Oligocene and the middle Miocene, the climate and topographic conditions of has changed of this area (Bayari et al. 2019). These changes caused glaciation in the Quaternary (Altın 2003). During the Last Glacial Maximum (LGM), valley glaciers extended down to $1500 \mathrm{~m}$ on the western flanks and $1100 \mathrm{~m}$ on the eastern flanks of the Aladağlar Mts. (Sarıkaya and Çiner 2017). During the LGM, freez-thaw processes was dominated the lower parts of the study area and surrounding. After LGM, continuous melting of glaciers on the western flank resulted in the formation of a large sandur deposit by alluvial fans extending over the Ecemiş Fault (Sarıkaya et al. 2015; Y1ldırım et al. 2016).

The Emli River Basin, which drains into Ecemiş River, covers $76.07 \mathrm{~km}^{2}$ area and the elevation of the basin ranges from 1350 to $3723 \mathrm{~m}$ (Küçükemler Peak). The upper part of the basin is covered by glacial cirques
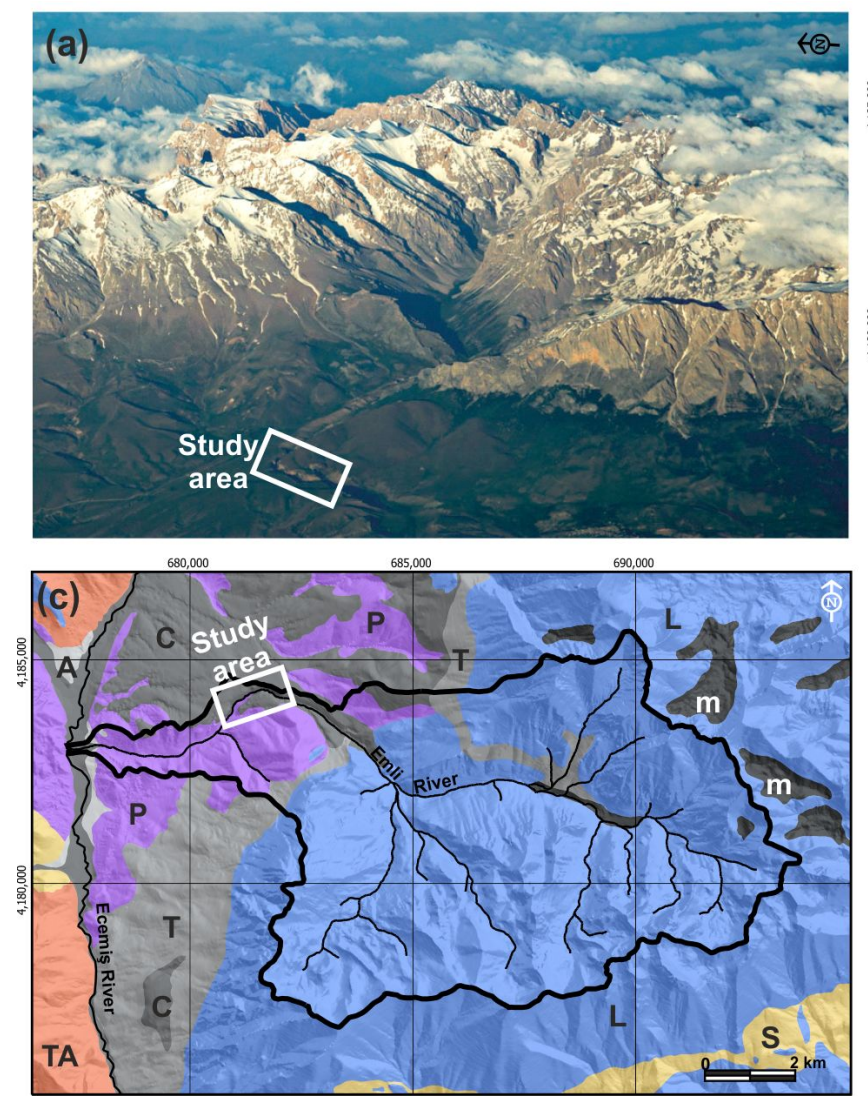

formed during LGM. Due to glacial and fluvial erosion, the valley is surrounded by steep slopes, especially in the upper part of the basin (Fig. 2b). Emli River basin consists mostly of limestone and the Quaternary alluvial fan (Emli Fan), which is mainly composed of well-lithified rounded to sub-rounded creamy white and dark gray limestone cobbles (Fig. 3e,f) in the lower parts of the basin (Figs. 2c, 3 ). This fan is comprised of crudely stratified thick beds with a total thickness reaching up to about $80 \mathrm{~m}$ (Fig. 3b, c, d). The oldest fan surface sediments were deposited $97 \mathrm{ka}$ ago during Marine Isotope Stage 5 (MIS 5) (Sarıkaya et al. 2015) and Kazıkliali gorge was carved into this Late Quaternary alluvial fan of Emli River (Fig. 3).

According to 25 years of data belongs to Çamard1 Meteorology Station $(1500 \mathrm{~m})$ located $10 \mathrm{~km}$ west of the Kazıklıali Canyon, the average annual temperature and total precipitation are $8.9^{\circ} \mathrm{C}$ and $328 \mathrm{~mm}$. The highest precipitation is observed in April (48 mm) and May (46 $\mathrm{mm}$ ). July-September is the arid period and the mean total precipitation in this period is $7.4 \mathrm{~mm} /$ month. While the average temperatures are below zero during winter months, they rise to $20^{\circ} \mathrm{C}$ during summer months. Maximum temperatures rise to $35^{\circ} \mathrm{C}$ and minimum temperatures decrease to $-25^{\circ} \mathrm{C}$ during the summer and winter periods. Freezing occurs 102 days of the year according to minimum temperatures $\left(\operatorname{Min}<0^{\circ} \mathrm{C}\right)$. While the Aladağlar Mountains have a dry summer continental climate (Dsb), the Çamard 1 Station has a cold semi-arid climate (BSk) according to Köppen-Geiger classifications (Öztürk et al. 2017).

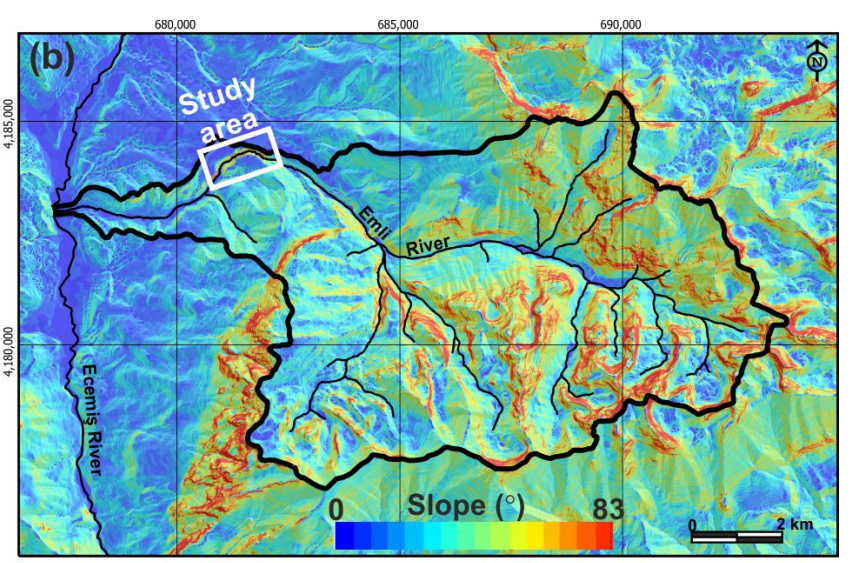

\section{Legend for geology map}

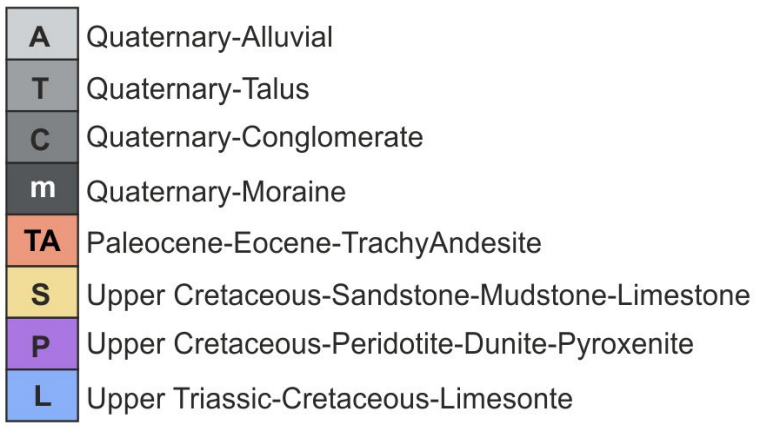

Figure 2. a) Aerial photo showing Emli River basin and study area (photo courtesy of Turgut Tarhan) with (b) slope and (c) geology maps of Emli River basin. 

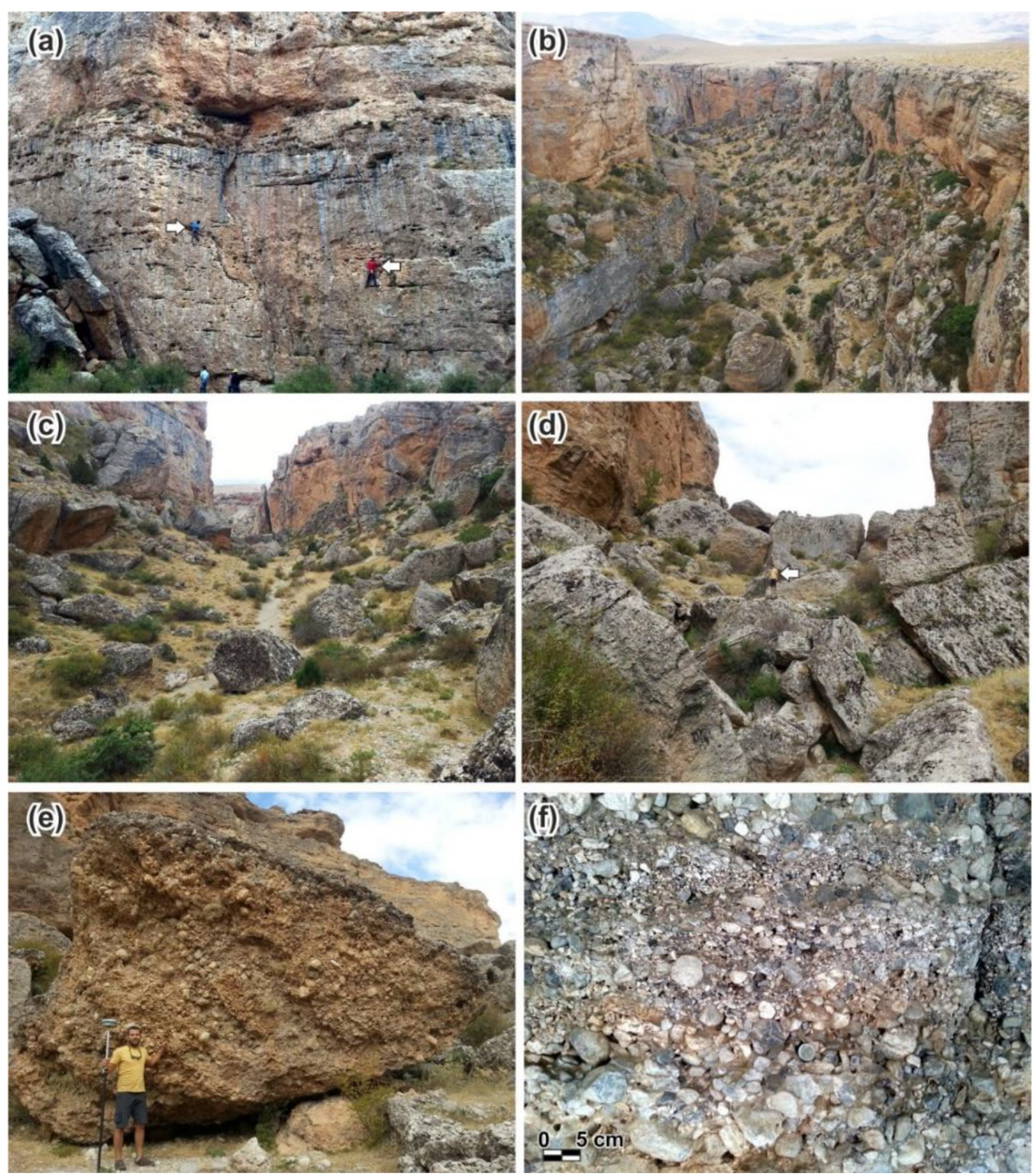

Figure 3. Photos from the study area. (a) Climbers on rock surface (white arrows show climbers), (b, c, d) fallen rock blocks in gorge (white arrows show scale in $\mathrm{c}),(\mathrm{e}, \mathrm{f})$ conglomeratic texture of fallen blocks in the gorge.

\section{Materials and Method}

Geographical Information Systems (GIS) play an important role especially in earth science which management and in mitigation, hazard and risk studies (Cancelli and Crosta 1994; Y1lmaz et al. 2008; Antoniou and Lekkas 2010). Besides, in recent years unmanned aerial vehicles (UAV) have seen great improvements that offer enormous advantages for mapping and monitoring in a short period, mostly on a local scale (Boccardo et al. 2015; Yusoff et al. 2018) and unmanned aerial vehicles have become widespread in different application areas. Like many important developments, UAV systems, which have been used mostly for military purposes, are now widely used in civilian applications recently (Erenoğlu and Erenoğlu, 2018). UAVs could be utilized for Earth observation, geomorphology, environment monitoring etc. UAVs are cheaper, smaller, lighter, practical and more user friendly than all other geoinformatics observation equipment. In addition to being able to provide many different equipment as a mobile operator with economic efficiency, it is preferred by researchers due to their many other features, such as UAV's ability to provide high-resolution images. UAVs typically fly at low altitudes to obtain remote sensing data (Ollero and Merino, 2006). Although expectations produce advantages in the launch of a innovative technology, overly high expectations may have a unfavorable impact on knowledge implementation (Freeman and Freeland, 2015; Bayırhan and Gazioglu, 2020). UAVs have also 
been widely-used in natural hazard observations and rockfall risk assessment (Chou et al., 2010; Giordan et al. 2015; Salvini et al. 2017). The UAV allows us to obtain highly detailed information to determine and understand the spread of rockfall boulders (Van Veen et al. 2018). Furthermore, rockfall softwares are important in evaluating management risk resilience and hazard decrease, also in understanding the physical characteristics of a rockfall, such as its energy, velocity and runout distance.

In this study, an orthophoto image created via UAV images was analyzed to determine the spatial distribution of rockfalls and their characteristics. Air photos were captured using DJI Phantom 4 advanced. In total, 553 aerial photos from a height of 100 meters were collected via two planned drone flights with conventional parallel flight lines (Fig. 4a). Moreover, 15 ground control points (GCP) were marked before the drone flights. Then, an orthophoto and a DSM of $3 \mathrm{~cm}$ resolution were created with all the photos processed in Pix4D software (trial version; Fig. 4b). Only fallen rock blocks of more than $0.5 \mathrm{~m}$ diameter in the valley were digitized as polygons in GIS software. By means of these polygons, density maps were created and frequency distribution was calculated (Fig. 5). For the density maps, the Kernel density estimation method was used. This method is often employed in visualizing and analyzing the spatial data of the point data. Rockfall analyses were performed in the canyon based on RAMMS, which is mass movement software. The rockfall model based on RAMMS software (RAMMS-RockFall Module 1.6.70, 64 Bit) has many advantages for input to the DEM. RAMMS is a useful computer- based rockfall analysis 3D terrain model, enabling different rock mechanisms of the trajectories of different release point rockfall sources to be calculated. RAMMS can estimate kinetic energies, velocities, the jump heights of rockfalls, number of rock deposits, and statistical values (Vo, 2015). The RAMMS model takes into account different terrain types: soft, medium soft, medium, medium-hard, hard, extra hard and snow; which is modeled accurately (Bartelt et al., 2016) and controlled by digitizing in the polygons, as well as differentiating forest types. To evaluate the rockfall's kinetic energy, trajectories, velocity and jump height, were used a $1 \mathrm{~m}$ resolution DSM, which was created from the $3 \mathrm{~cm}-$ resolution DSM.

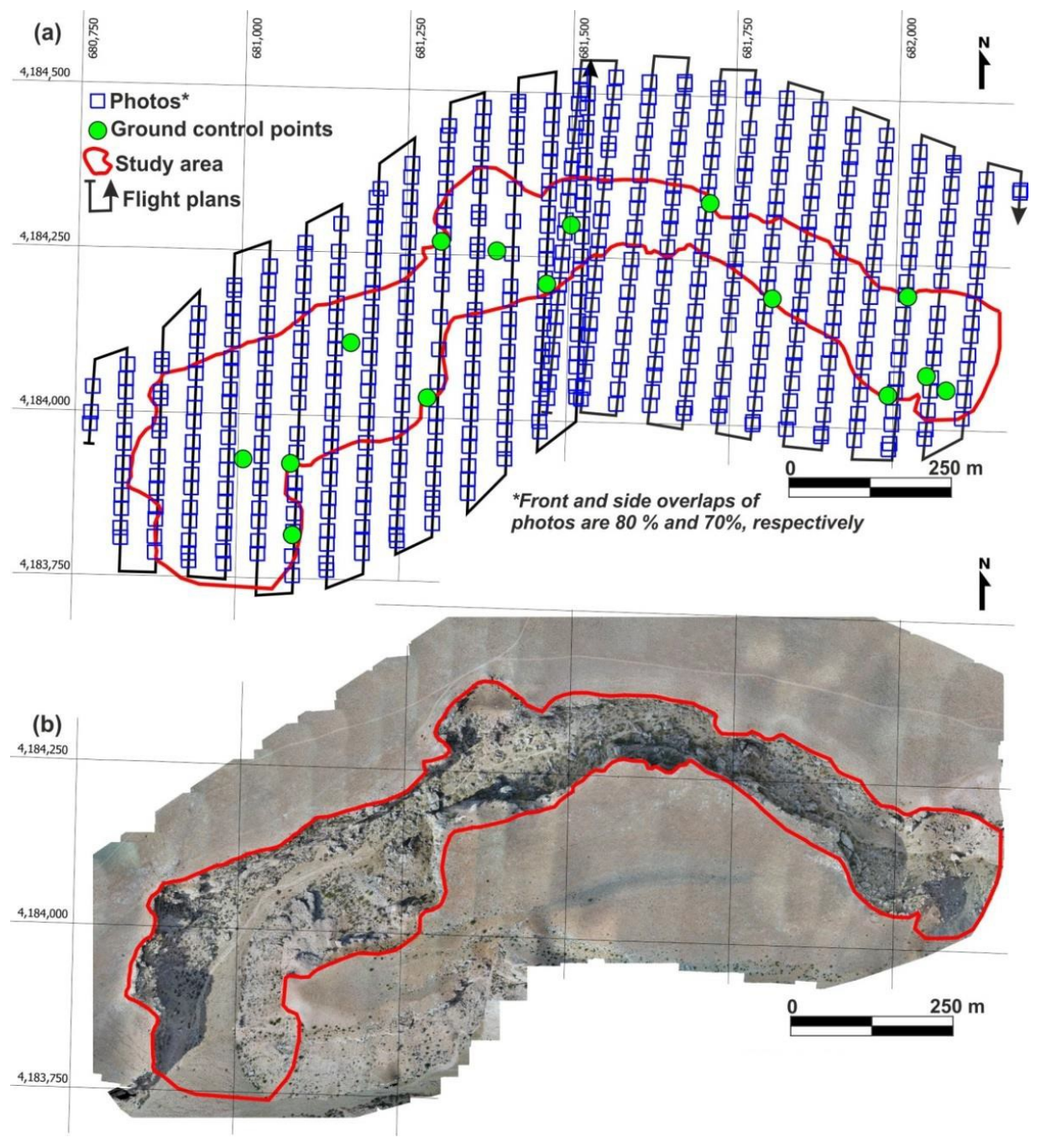

Figure 4. (a) Locations of aerial photos, ground control points, and flight plans. (b) Orthophoto of study area (UTM zone 36). 


\section{Results}

\section{Distribution of rockfall}

According to the orthomosaic photo, the study area covers $0.25 \mathrm{~km}^{2}$ and is $1543 \mathrm{~m}$ in length in an east-west direction. The maximum and minimum widths of the canyon are $240 \mathrm{~m}$ and $60 \mathrm{~m}$, respectively (Fig. 5b). The central part of the canyon corresponds to the narrowest part. The average elevation of the study area is $1600 \mathrm{~m}$ and the elevation range is between 1527 and 1712 meters (Fig. 5a). The height of the canyon walls rises to 100 meters (Fig. 5b). The canyon walls are very steep and the maximum slope values are $90^{\circ}$ (Figs. 3 and 5).

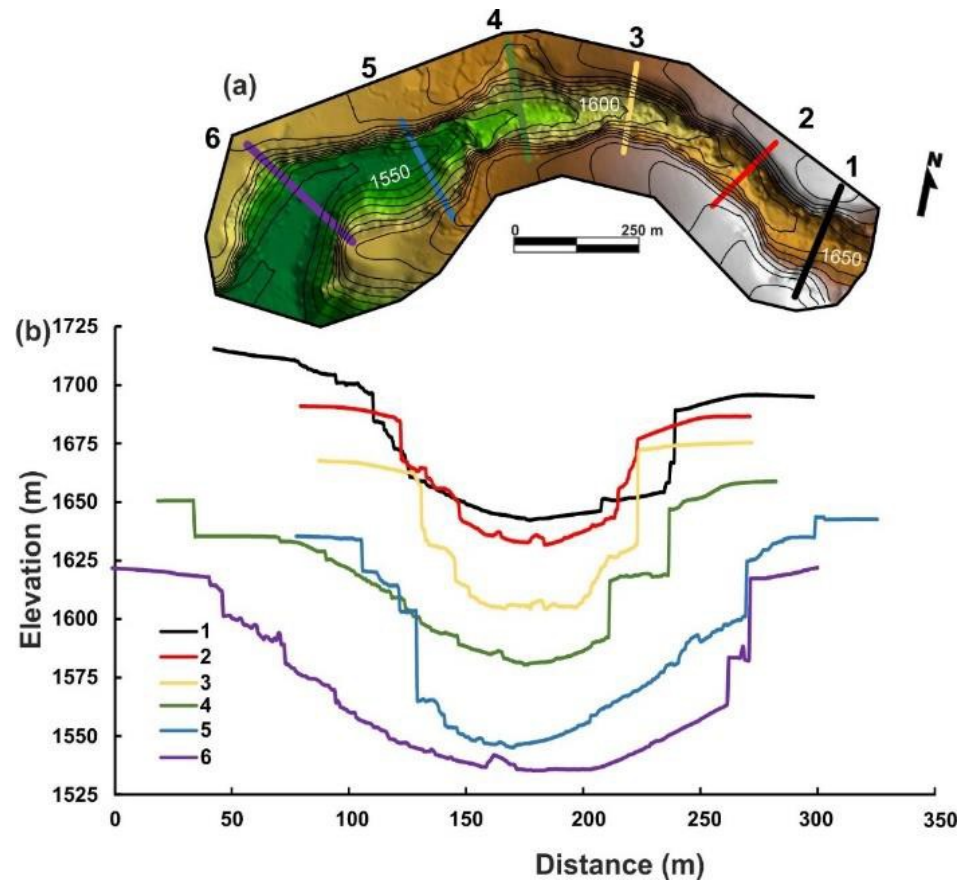

Figure 5. (a) Digital surface model of Kazıkliali Canyon (contour interval is $10 \mathrm{~m}$ ) and (b) cross-sections.

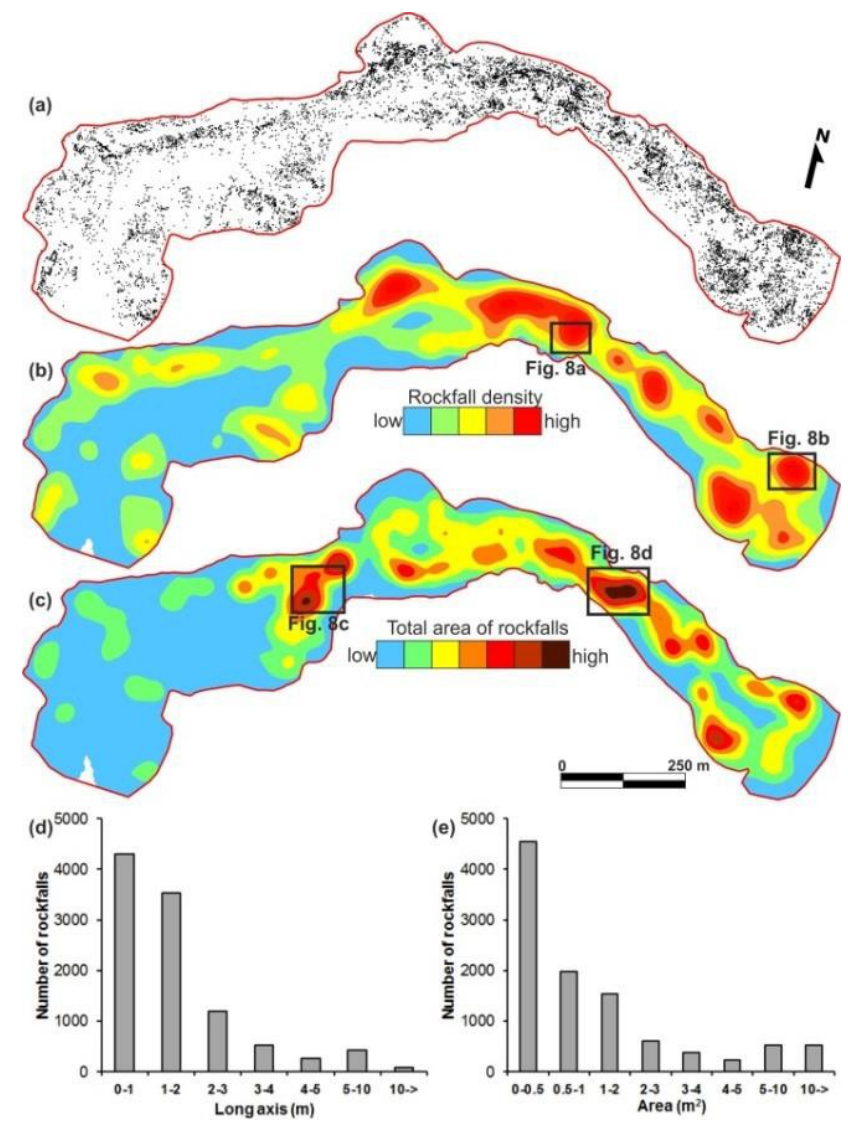

Figure 6. Spatial distribution of (a) rockfall blocks (b) rockfall density and (c) total surface area of the rockfall blocks. (d) Frequency distributions of the long axis and (e) surface area of the rockfall blocks. 
As a consequence of the digitizing, 10,348 fallen rock blocks more than $0.5 \mathrm{~m}$ in diameter were determined in Kazıklıali Gorge (Fig. 6a). Spatial distribution of the rockfall density and the total area of the fallen rocks are not homogenous. While the upper and middle parts of the canyon have high density, the lower part has low density. The width of the canyon is one of the important factors in this distribution since the upper and middle parts are narrow. Due to this, fallen rocks from two slopes combine in the central part (Figs. 6b; 8a, c, d). However, at the maximum width such as the lower (Fig. 6b) and uppermost parts (Fig. 8b), fallen rocks do not combine like the central part of the canyon (Fig. 8). In other words, a negative correlation is seen between canyon width and rockfall density. The spatial distribution of the total area has a similar distribution pattern (Fig. 6c). According to diameter frequency, $75.7 \%$ of fallen rocks have $<2$-m diameter and only $2.9 \%$ have $\geq 5 \mathrm{~m}$ diameter (Fig. $6 \mathrm{~d}$ ). Also, $78 \%$ of all fallen rocks have $<2 \mathrm{~m}^{2}$ and only $10.2 \%$ have $\geq 5 \mathrm{~m}^{2}$ surface area (Fig. 6e).

The lineaments on the canyon walls were digitized based on visual interpretation using high resolution orthophoto images. As a result, a totally 2174 lineaments were drawn (Fig 7a-b). The general orientation of all lineaments is WNW-ESE in direction (Fig. 7d). However, while the orientation of lineaments has WNW-ESE in direction at the upper and middle parts, it has a more heterogeneous direction at the lower part of the canyon. (Fig 7c).

\section{Rockfall Modeling}

The rockfall occurs frequently in Kazıkliali Gorge. The blocks break along the vertical cracks in conglomerates, fall over, and gather at places where the slope is less steep in the valley. The dimensions of these blocks reach $10 \mathrm{~m}$ (Fig. 3). Possible rockfall source points in the study area were determined using field studies and a digital surface model obtained by means of an unmanned aerial vehicle. In the entire canyon, heavily-dispersed rock falls are encountered (Fig. 6a). For this reason, all canyon walls were considered as possible rockfall areas. To achieve the maximum result, we started with blocks from the original canyon area with the highest slope values, i.e. which were probable sources.
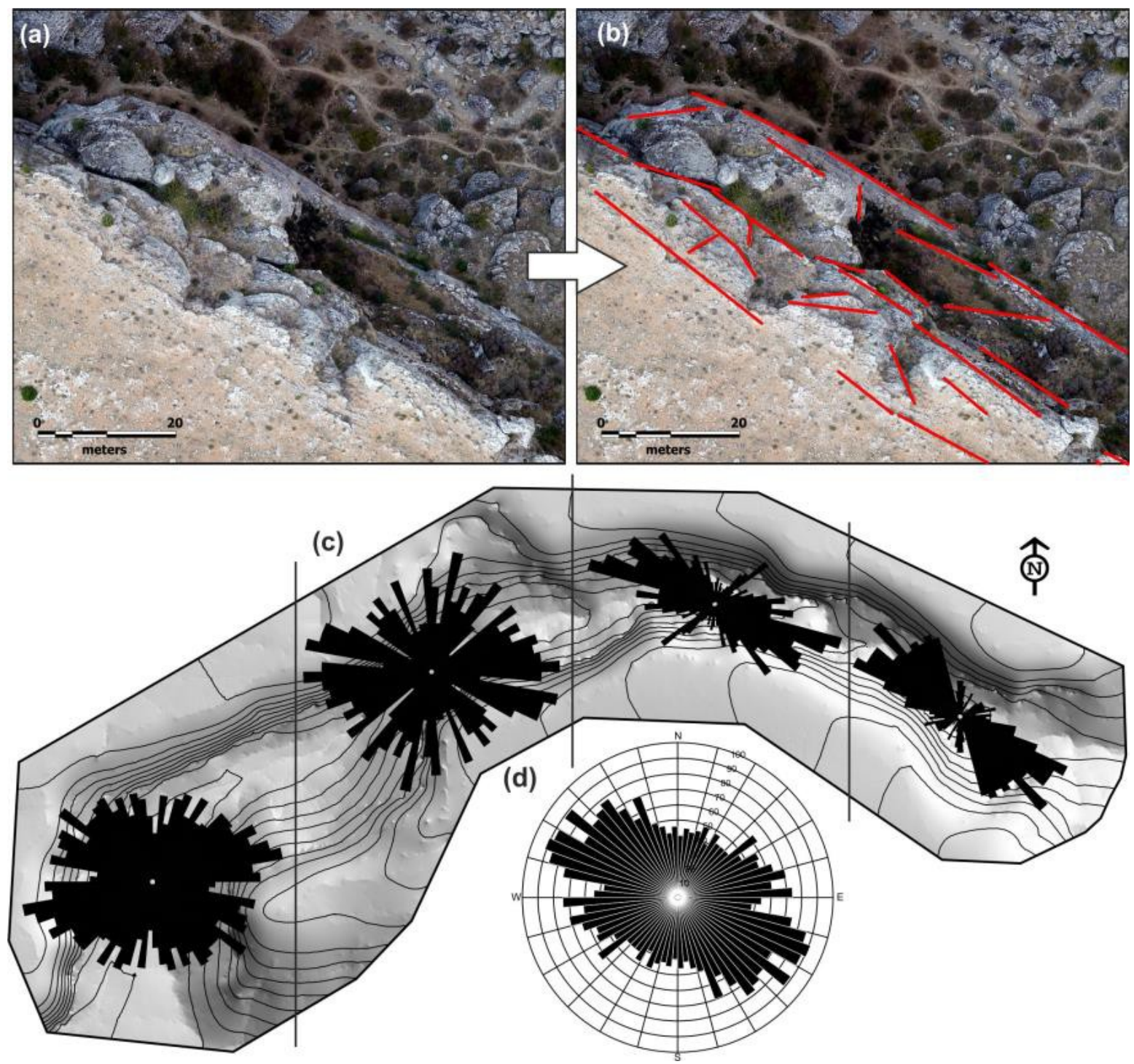

Figure 7. $(a, b)$ The lineaments extraction based on orthophoto image and (c) spatial distribution of lineaments in the canyon and (d) general orientation of all lineaments in the canyon. 

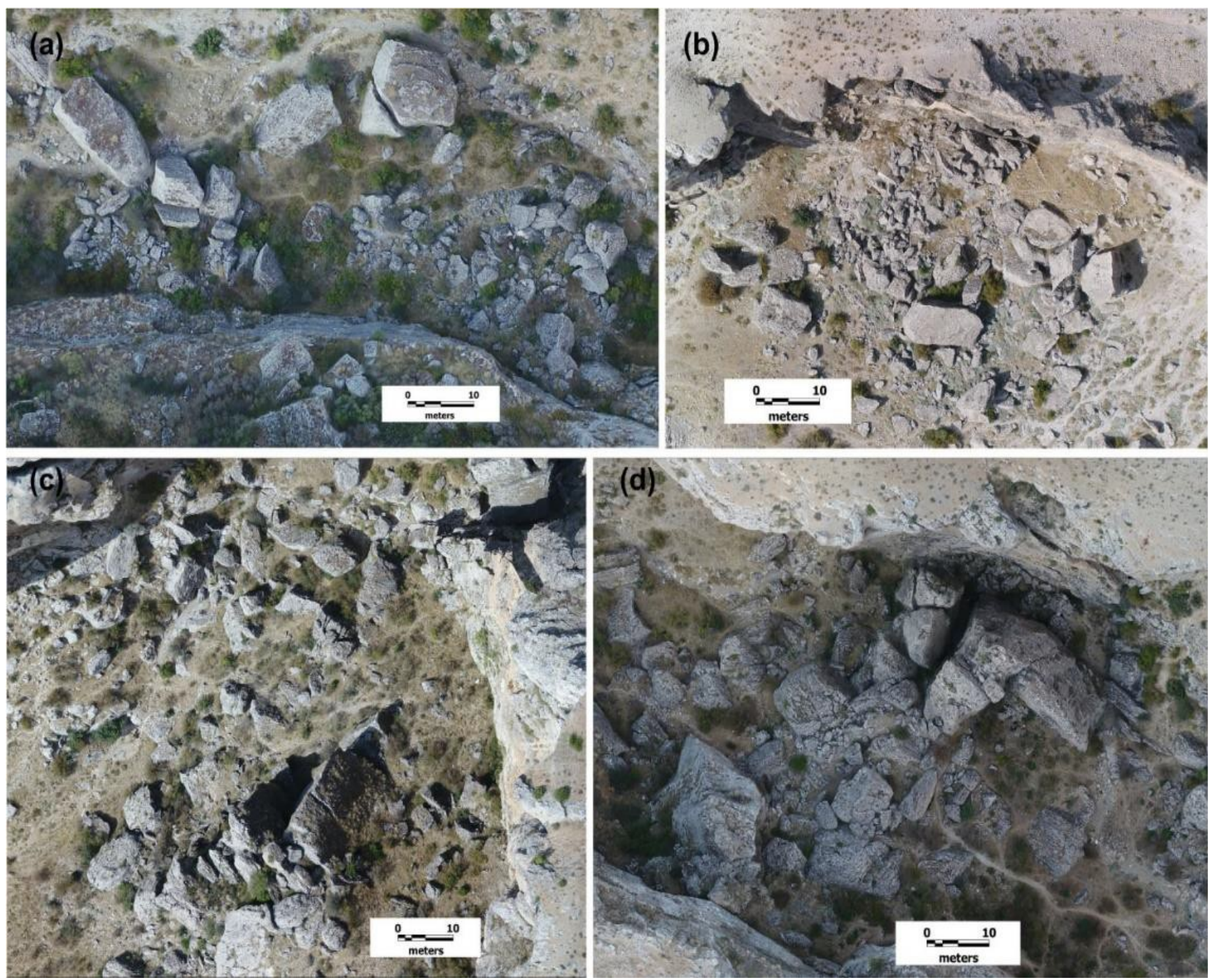

Figure 8. Examples of $(a, b)$ maximum densities and $(c, d)$ maximum total areas (Location of these photos is shown in Figure 6b,c).

Rockfall modeling was performed at Kazıklıali Gorge using Rockfall module of rapid mass movement software (RAMMS). To evaluate the kinetic energy, trajectories and velocities and jump height of the rockfall, a 1-m resolution DSM was used which was coverted from the $3 \mathrm{~cm}$ resolution DSM. In this study, the average of the rock boulders, ranging from $100 \mathrm{~m}^{3}$ to $2700 \mathrm{~m}^{3}$ and with a rock density of $2700 \mathrm{~kg} \mathrm{~m}^{3}$, was used to simulate the whole area. As well as this, input parameters of the hard terrain type were used in this study, based on their lithology type. The possible source of a rockfall area greater than the threshold of $55^{\circ}$ was selected based on rockfall modeling of the slope angle corresponding to a high rockfall source area (Fig. 9). Each parameter required for modeling the rock falls was evaluated and prepared for modeling.

Overall, 100 blocks were modeled at each 1000 source points along the valley walls to test the maximum energy, jump height and velocity. Since all canyon walls represent a possible area for rock climbing, results showed that rockfall velocities $(\mathrm{m} / \mathrm{s})$, kinetic energies $(\mathrm{kJ})$ and rock jump heights $(\mathrm{m})$ reached their highest level at the slope failure/inclination points (Fig. 9).

According to the results of the rockfall analysis, the velocity range was from 0 to $32 \mathrm{~m} / \mathrm{s}$ (Fig. 9a), kinetic energy 0-1400 kJ (Fig. 9b), and jump height 0-15 m (Fig. $9 \mathrm{c})$. The high rockfall hazard areas correspond to the steeper slope areas. Due to the geomorphology of the canyon, it can be seen on the highly sloping canyon edges that the middle of the valley, representing maximum velocity, energy and jump height, has minimum values. It is also observed that the low values indicate canyon outlets. Areas with steep slopes with high slope values correspond to the transport zone, while the middle of the valley where the slope values are low corresponds to the accumulation zone of rock falls. 


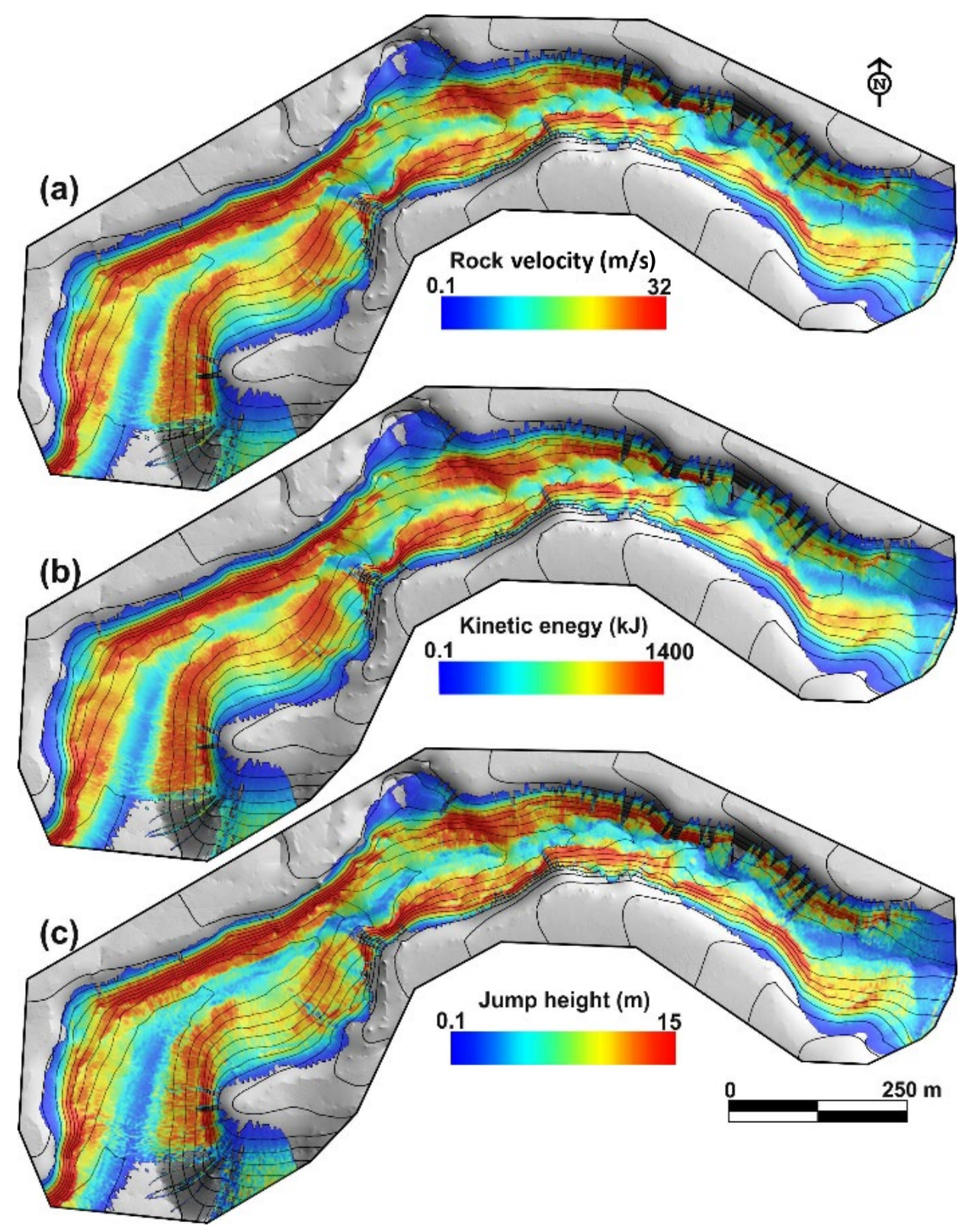

Figure 9. RAMMS results: (a) rockfall source velocities (b) rockfall kinetic energies and (c) rockfall jump heights of different rock samples.

The results of the RAMMS 3D simulation shows the trajectories spreading about $90 \mathrm{~m}$ from the source point (Fig. 10a) and descending between 1660 and $1580 \mathrm{~m}$. Most of the trajectories stopped at the flat-surfaced middle part of the gorge (Fig. 10a). An example of the trajectory results shows that the transition zone represents high velocity, energy and jump. Also, the source of the rock area slides along the steep slope results in low energy, jump and velocity because of the friction (Chen et al. 2013).
However, the middle parts of the slope correspond to a steep slope and not much friction, which results in a high jump (Fig. 10a), velocity (Fig. 10b) and energy (Fig. 10c). The given cross-section of the trajectory shows two peak values, meaning that high slope values have a high jump height and kinetic energy and low friction. While the source and accumulation zone have high friction, the transition zone has low friction and high rock energy and velocity. 

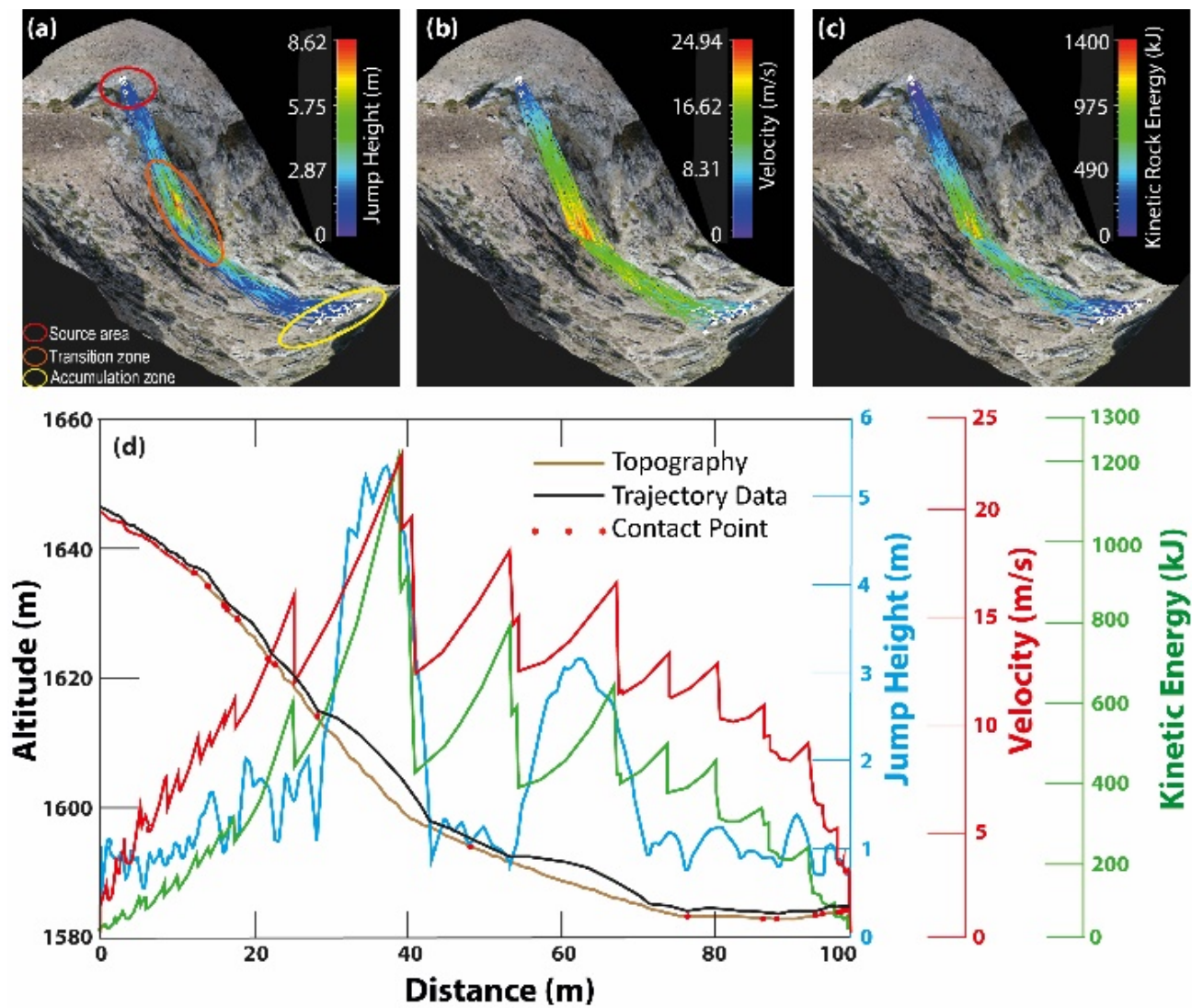

Figure 10. 3D simulation of block tested on trajectory simulator using RAMMS rockfall modeling in narrowest part of gorge: (a) jump height (b) velocity (c) kinetic rock energy. (d) Examples of rockfall kinetic energy, velocity and jump height obtained from a trajectory.

\section{Conclusion}

Until recently, most rockfall modeling studies were carried out with $\pm 10 \mathrm{~m}$ resolution DEMs data using 1:25000 scaled topographic maps. DEM data obtained from these topographic maps do not represent topography well, especially rockfall modeling studies. UAV technology provides improved high-resolution images DTM and DSM data compared with Topo DEM data. Besides, it represents topography well and detailed than Topo DEM. For this reason, UAV technology was used to generate high-resolution orthophoto and DEM data of the study area. In this study, rockfall modeling was performed at Kazıklıali Gorge using rockfall module of rapid mass movement software (RAMMS). ArcGIS 10.x software was also used to generate GIS data on the rockfall source area to identify terrain differences and produce a slope map. About 1000 rockfall source areas were identified based on the $3-\mathrm{cm}$ resolution orthophoto and slope map. 100 blocks were simulated based on each of the 1000 source areas; this corresponds to 100,000 rockfalls being modeled in this study.

To determine the spatial distribution and frequencies of the fallen rock blocks, an orthophoto image and a digital surface model of $3 \mathrm{~cm}$ resolution were used. As a result, 10,348 fallen rock blocks of more than $0.5 \mathrm{~m}$ diameter were determined in Kazıkliali Canyon. Spatial distribution of the rockfall density and total area of the fallen rocks are not homogenous in the canyon. While the upper and middle parts of the canyon have a high density, the lower part has a low density. The width of the canyon is an important factor in this distribution. This is due to the narrowness of the width of the upper and middle parts of the gorge; hence fallen rocks from two slopes combine in the central part. According to diameter frequency, $75.7 \%$ of fallen rocks have $<2$-meter diameter and only $2.9 \%$ have $\geq 5 \mathrm{~m}$ diameter. In terms of surface area, $78 \%$ of the fallen rocks have an area of $<2 \mathrm{~m} 2$ and only $10.2 \%$ measure $\geq 5 \mathrm{~m} 2$. Depending on the RAMMS results, the rockfall velocities, kinetic energies and rock jump heights reach their highest level at the slope failure/inclination points. The possibility of rockfalls is most likely where the gorge is at its narrowest and there are high, steep slopes. According to the results of our rockfall analysis, the velocity ranges from 0 to $32 \mathrm{~m} / \mathrm{s}$, the kinetic energy is $0 * 1400 \mathrm{~kJ}$ and the jump height is between 0 and $15 \mathrm{~m}$. In summary, the Kazıkliali Canyon can be considered a high rockfall hazard area in consequence of the high steep slopes, especially in the narrowest part of the canyon.

\section{References}

Abebe, B., Dramis, F., Fubelli, G., Umer, M., Asrat, A. (2010). Landslides in the Ethiopian highlands and the Rift margins. J African Earth Sci, 56:131-138. DOI: 10.1016/j.jafrearsci.2009.06.006.

Altın, T. (2003). Aladağlar üzerinde (Ecemiş Çayı Aklanı) buzul ve karst jeomorfolojisi. Glacial and karst geomorphology on Aladag Mountains (Ecemis river basin) Ístanbul University, Social Science Inst. $\mathrm{PhD}$ thesis (unpublished), p. 513.

Antoniou, A.A., Lekkas, E. (2010). Rockfall susceptibility map for Athinios port, Santorini Island, Greece. Geomorphology, 118:152-166. DOI: 
10.1016/j.geomorph.2009.12.015

Ashfield, J.R. (2001). The computer simulation and prediction of rock fall. Doctoral thesis, Durham University

Aydın, A., Köse, N., Akkemik, Ü., Yurtseven, H. (2012). Assessment and analysis of rockfall-caused tree injuries in a Turkish fir stand: A case study from Kastamonu-Turkey. $J$ Mt Sci, 9:137-146. DOI: $10.1007 / \mathrm{s} 11629-012-2233-9$

Aydın, A. (2007). Ormanlık Alanlarda Taş ve Kaya Yuvarlanmaları. IÜ Orman Fakültesi Dergisi 57:127144

Aydın, A., Eker, R. (2017). Kaya yuvarlanmalarından etkilenen orman alanlarının belirlenmesi: İnebolu örneği. İ̈ Orman Fakültesi Dergisi, 67:1-1. DOI: 10.17099/jffiu. 281710

Bartelt, P., Bieler, C., Bühler, Y., Christen, M., Christen, M., Dreier, L., Gerber, W., Glover, J., Schneider, M., Glocker, C., Leine, R., Schweizer, A. RAMMS:: Rockfall, SLF, WSL, ETH.

Bayari, S., Klimchouk, A., Sarıkaya, M., Nazik, L. (2019). Aladağlar Mountain Range: A LandscapeShaped by the Interplay of Glacial, Karstic, and Fluvial Erosion. In: Landscapes and Landforms of Turkey. Springer International Publishing, 423-435

Bayırhan, I., Gazioğlu, C. (2020). Use of Unmanned Aerial Vehicles (UAV) and Marine Environment Simulator in Oil Pollution Investigations, Baltic $J$. Modern Computing, 8(2), 327-336, DOI: 10.22364/bjmc.2020.8.2.08.

Binal, A., Ercanoğlu, M. (2010). Assessment of rockfall potential in the Kula (Manisa, Turkey). Geopark Region. Environ Earth Sci, 61:1361-1373. DOI: 10.1007/s12665-010-0454-1

Boccardo. P., Chiabrando, F., Dutto, F., Tonolo, F.B., Lingua, A. (2015). UAV Deployment Exercise for Mapping Purposes: Evaluation of Emergency Response Applications. Sensors, 15: 15717-15737. DOI: $10.3390 / \mathrm{s} 150715717$

Bull, W.B., King, J., Kong, F., Moutoux, T., Philips, W.M. (1994). Lichen dating of coseismic landslide hazards in alpine mountains. Geomorphology, 10:253-264

Cancelli, A., Crosta, G. (1994). 15. Hazard and risk assessment in rockfall prone areas. In: Risk and reliability in ground engineering. Thomas Telford Publishing, 177-190

Chau, K.T., Wong, R.H.C., Liu, J., Lee, C.F. (2003). Rockfall Hazard Analysis for Hong Kong Based on Rockfall Inventory. Rock Mech Rock Eng, 36:383-408. DOI: 10.1007/s00603-002-0035-Z

Chen, G., Zheng, L., Zhang, Y., Wu, J. (2013). Numerical simulation in rockfall analysis: A close comparison of 2-D and 3-D DDA. Rock Mech Rock Eng, 46:527-541. DOI: 10.1007/s00603-012-0360-9

Chou, T., Yeh, M., Chen, Y., Chen,. Y. (2010). Disaster monitoring and management by the unmanned aerial vehicle technolgy,. In: Wagner W., Székely, B. (eds.).: ISPRS TC VII Symposium - 100 Years ISPRS, Vienna, Austria, July 5-7, 2010, IAPRS, Vol. XXXVIII, Part 7B.

Cruden, D.M., Varnes, D.J. (1996). Landslide Types and Processes, Special Report, Transportation Research Board, National Academy of Sciences, 247:36-75. Washington

Cybulski, P.G. (2014). Rock Fall Mitigation for an Open Pit Mine Experiencing Substantial rock fall from overblasting. Faculty and the Board of Trustees of the Colorado School of Mines, Degree of Master of Science, Geological Engineering.

Dietze, M., Turowski, J.M., Cook, K.L., Hovius, N. (2017). Spatiotemporal patterns, triggers and anatomies of seismically detected rockfalls. Earth Surf Dyn, 5:757-779. DOI: 10.5194/esurf-5-7572017

Dinçer, İ., Orhan, A., Frattini, P., Crosta, G.B. (2016). Rockfall at the heritage site of the Tatlarin Underground City (Cappadocia, Turkey). Nat Hazards, 82:1075-1098. DOI: 10.1007/s11069-0162234-z

Dorren, L.K.A. (2003). A review of rockfall mechanics and modelling a roaches. Prog Phys Geogr, 27:6987. DOI: $10.1191 / 0309133303$ 359ra

Dorren, L.K.A., Seijmonsbergen, A.C. (2003). Comparison of three GIS-based models for predicting rockfall runout zones at a regional scale. Geomorphology, 56:49-64. DOI: 10.1016/S0169$555 \mathrm{X}(03) .00045-\mathrm{X}$.

Ergünay, O. (2007). Türkiyenin Afet Profili. In: TMMOB Afet Sempozyumu. Ankara, 1-14

Erenoğlu, R, Erenoğlu, O. (2018). A case study on the comparison of terrestrial methods and unmanned aerial vehicle technique in landslide surveys: Sarıcaeli landslide, Çanakkale, NW Turkey. International Journal of Environment and Geoinformatics, 5 (3), 325-336. DOI: 10.30897/ijegeo.468061.

Erismann, T.H., Abele, G. (2001). Dynamics of rockslides and rockfalls. Springer.

Flageollet, J.C., Weber, D. (1996). Fall. In: Dikau R, Brunsden D, Schrott L, Ibsen ML (eds). Landslides Recognition. Identification, Movement and Causes. Wiley, Chichester, 13-28.

Freeman, P.K., Freeland, R.S. (2015). Agricultural UAVs in the U.S.: potential, policy, and hype, Remote Sensing Applications: Society and Environment, Vol.2:35-43.

Geniş, M., Sakız, U., Aydıner, Ç.B. (2017). A stability assessment of the rockfall problem around the Gökgöl Tunnel (Zonguldak, Turkey). Bull Eng Geol Environ, 76:1237-1248. DOI: 10.1007/s10064-016- 0907-1.

Giordan, D., Manconi, A., Facello, A., Baldo, M., Dell'anese, F., Allasia, P., Dutto, F. (2015). Brief Communication: The use of an unmanned aerial vehicle in a rockfall emergency scenario. Nat Hazards Earth Syst Sci, 163-169. DOI: 10.5194/nhess-15-1632015.

Gökçe, O., Özden, Ş., Demir, A. (2008). Türkiye'de afetlerin mekansal ve istatistiksel dağllımı, Afet bilgileri envanteri. Ankara.

Gül, M., Özbek, A., Karacan, E. (2016). Rock fall hazard assessment in Asar Hill, ancient Mabolla City, MuglaSW Turkey. Environ Earth Sci, 75:. DOI: 10.1007/s12665-016-6113-4. 
Hoek, E. (2007). Practical rock engineering e-book.

Karaağaç, D. (2019). Kahramanmaraş ve yakın çevresi için deprem senaryolarinin hazirlanmasi ve mekânsal (spatial). analiz teknikleriyle yerleşime uygun alanlarin belirlenmesi, Ankara Üniversitesi Fen Bilimleri Enstitüsü, Yüksek lisans tezi. Ankara.

Kaya, Y., Topal, T. (2015). Evaluation of rock slope stability for a touristic coastal area near Kusadas1, Aydın (Turkey).. Environ Earth Sci, 74:4187-4199. DOI: $10.1007 / \mathrm{s} 12665-015-4473-9$.

Kayabaşı, A. (2018). The assesment of rockfall analysis near a railroad: a case study at the Kizilinler village of Eskişehir, Turkey. Arab $J$ Geosci, 11:. DOI: 10.1007/s12517-018-4175-1.

Keskin, İ. (2013). Evaluation of rock falls in an urban area: the case of Boğaziçi (Erzincan/Turkey).. Environ Earth Sci, 70:1619-1628. DOI: 10.1007/s12665-0132247-9.

Kutluca, A.K. (2006). In: The Izmir City and Natural Hazard Risks. 46th Congress of the European Regional Science Association: "Enlargement, Southern Europe and the Mediterranean.

Matsuoka, N. (1999). Rockfall activity from an alpine cliff during thawing periods. Geomorphology, 28: 309-328.

McCarroll, D., Shakesby, R.A., Matthews, J.A. (1998). Spatial and Temporal Patterns of Late Holocene Rockfall Activity on a Norwegian Talus Slope: A Lichenometric and Simulation-Modeling A roach. Arctic and Alpine Research, 30 (1): 51-60.

Michoud, C., Derron, M., Horton, P., Jaboyedoff, M., Baillifard, F.J., Alexandre, L., Nicolet, P., Pedrazzini, A., Qeyrel, A. (2012). Rockfall hazard and risk assessments along roads at a regional scale: example in Swiss Alps. Nat. Haz. and Earth Sys. Sci., 615-629. DOI: 10.5194/nhess-12- 615-2012

Mineo, S., Pappalardo, G., Mangiameli, M., Campolo, S., Mussumeci, G. (2018). Rockfall Analysis for Preliminary Hazard Assessment of the Cliff of Taormina Saracen Castle (Sicily). Sustainability, 10 (2): 417. DOI: 10.3390/su10020417.

Ollero, A., Merino, L., (2006). Unmanned aerial vehicles as tools for forest-fire fighting, For. Ecol. Manage. 234(15), S263.

Özgül, N. (1983). Stratigraphy and tectonic evolution of the central Taurides. In: Tekeli $\mathrm{O}$, Göncüoğlü $\mathrm{MC}$ (eds). Geology of the Taurus Belt, MTA, Ankara. 77-90.

Özturk, H.S., Kocaman, S., Gokceoglu, C. (2019). A low-cost a roach for determination of discontinuity orientation using smartphone images and application to a part of Ihlara Valley (Central Turkey). Eng Geol, 254:63-75. DOI: 10.1016/j.enggeo.2019.04.011.

Öztürk, M.Z., Çetinkaya, G., Aydın, S. (2017). KöppenGeiger İklim Sınıflandırmasına Göre Türkiye'nin İklim Tipleri. Coğrafya Derg, 17-27.

Parise, M. (2002). Landslide hazard zonation of slopes susceptible to rock falls and to les. Nat Hazards Earth Syst Sci, 2:37-49. DOI: 10.5194/nhess-2-372002.

Pellicani, R., Spilotro, G., Van, Westen. C.J. (2016). Rockfall trajectory modeling combined with heuristic analysis for assessing the rockfall hazard along the Maratea SS18 coastal road (Basilicata, Southern Italy). Landslides, 13:985-1003. DOI: 10.1007/s10346-015-0665-3.

Polat, A., Keskin, I., Denizli, I. (2016). Preventing and analysis of falling rocks: A case of Sarica village (Gürün, Turkey).. J Geol Soc India 88:763-772. DOI: 10.1007/s12594-016-0544-0.

Porter, S.C., Orombelli, G. (1981). Alpine Rockfall Hazards: Recognition and dating of rockfall deposits in the western Italian Alps lead to an understanding of the potential hazards of giant rockfalls in mountainous regions. American Scientist, 69(1), 67-75.

Salvini, R., Mastrorocco, G., Seddaiu, M., Rossi, D., Vanneschi, C. (2017). The use of an unmanned aerial vehicle for fracture mapping within a marble quarry (Carrara, Italy).: photogrammetry and discrete fracture network modelling discrete fracture network modelling. Geomatics, Nat Hazards Risk, 5705. DOI: 10.1080/19475705.2016.1199053.

Sarıkaya, A.M., Yıldırım, C., Çiner, A. (2015). Late Quaternary alluvial fans of Emli Valley in the Ecemiş Fault Zone, south central Turkey: Insights from cosmogenic nuclides. Geomorphology, 228:512-525.

DOI: 10.1016/J.GEOMORPH.2014.10.008.

Sarıkaya, M.A., Çiner, A. (2017). Late Quaternary glaciations in the eastern Mediterranean. Geol Soc, London, Spec Publ 433:289-305. DOI: 10.1144/SP433.4.

Schneuwly, D.M., Stoffel, M. (2008). Geomorphology Spatial analysis of rockfall activity, bounce heights and geomorphic changes over the last 50 years - A case study using dendrogeomorphology. Geomorphology, 102: 522-531. DOI: 10.1016/j.geomorph.2008.05.043.

Strunden, J., Ehlers, T.A., Brehm, D., Nettesheim, M. (2015). Spatial and temporal variations in rockfall determined from TLS measurements in a deglaciated valley, Switzerland. J Geophys Res F Earth Surf, 120:1251-1273. DOI: 10.1002/2014JF003274.

Şahin, Y., Altın, F.G. (2016). Çadırkent yer seçimi problemi için bir atama modeli: Isparta örneği - an assignment model for shelter site selection problem: a case of Isparta. Mehmet Akif Ersoy Üniversitesi Sosyal Bilim Enstitüsü Derg, 8:. DOI: 10.20875/sb.35069

Şener, E. (2019). İnsansız hava araçları kullanılarak olası kaya düşmelerinin coğrafi bilgi sistemleri tabanlı 3d modellenmesi: Kasımlar Köyü (IspartaTürkiye). Örneği. Süleyman Demirel Üniversitesi Fen Bilim Enstitüsü Derg, 143-150. DOI: 10.19113/sdufenbed.501482.

Taga, H., Zorlu, K. (2016). Assessment of rockfall hazard on the steep-high slopes: Ermenek (Karaman, Turkey). Nat Hazards Earth Syst Sci, Discuss 1-32. DOI: 10.5194/nhess-2015-337.

Tekeli, O., Aksay, A., Urgun, B.M., İslik, A. (1983). Geology of the Aladag mountains. In: Tekeli O, Goncüöğlü MO (eds). Geology of the Taurus Belt. Proc. Internat. Symp., Turkey,. 143-158.

Topal, T., Akin, M., Ozden, U.A. (2007). Assessment of 
rockfall hazard around Afyon Castle, Turkey. Environ Geol, 53:191-200. DOI: 10.1007/s00254- 006-0633-2.

Topal, T., Akin, M.K., Akin, M. (2012). Rockfall hazard analysis for an historical Castle in Kastamonu (Turkey). Nat Hazards, 62:255-274. DOI: 10.1007/s11069-011-9995-1.

Topal, T., Hatipoglu, O. (2015). Assessment of slope stability and monitoring of a landslide in the Koyulhisar settlement area (Sivas, Turkey). Environ Earth Sci. 74: 4507-4522. DOI: 10.1007/s12665015-4476-6.

Török. Á., Barsi, Á., Bögöly, G. Lovas, T., Somogyi, A., Görög, P. (2017). Slope stability and rock fall hazard assessment of volcanic tuffs using RPAS and TLS with 2D FEM slope modelling. Nat Hazards Earth Syst Sci, Discuss 1-30. DOI: 10.5194/nhess-2017-56.

Tunusluoglu, M.C., Zorlu, K. (2009). Rockfall hazard assessment in a cultural and natural heritage (Ortahisar Castle, Cappadocia, Turkey). Environ Geol, 56:963972. DOI: 10.1007/s00254-008-1198-z.

Ulusay, R., Gokceoglu, C., Topal, T., Sonmez, H., Tuncay, E., Erguler, Z.A. Kasmer, O. (2006). Assessment of environmental and engineering geological problems for the possible re-use of an abandoned rock-hewn settlement in Urgüp (Cappadocia)., Turkey. Environ Geol, 50:473-494. DOI: $10.1007 / \mathrm{s} 00254-006-0222-4$.

Van Veen, M., Jean Hutchinson D, Bonneau D.A. Ondercin, M., Lato, M. (2018). Combining temporal 3-D remote sensing data with spatial rockfall simulations for improved understanding of hazardous slopes within rail corridors. Nat Hazards Earth Syst Sci, 18: 2295- 2308. DOI: 10.5194/nhess-18-2295-2018.

Vidrih, R., Ribicic, M., Suhadolc, P. (2001). Seismogeological effects on rocks during the 12 April 1998 upper Soca Territory earthquake (NW Slovenia). Tectonophysics, 330:153-175.

Vijayakumar, S., Yacoub, T., Curran, J. (2011). On the effect of rock size and shape in rockfall analyses. San Francisco CA, USA.

Vo, D.T. (2015). RAMMS::Rockfall versus Rockyfor3D in rockfall trajectory simulations at the Community of Vik, Norway. Master Thesis in Geosciences Discipline: Environmental geology and geohazards, Department of Geosciences Faculty of Mathematics and Natural Sciences.

Whalley, W.B. (1984). Rockfalls, Slope Stab. Wiley,
New York

Yılmaz, I., Yildirim, M., Keskin, I. (2008). A method for mapping the spatial distribution of RockFall computer program analyses results using ArcGIS software. Bull Eng Geol Environ, 67:547-554. DOI: 10.1007/s10064-008-0174-x.

Yıldırım, C., Schildgen, T.F., Echtler, H., Melnick, D., Strecker, M.R. (2011). Late Neogene and active orogenic uplift in the Central Pontides associated with the North Anatolian Fault: Implications for the northern margin of the Central Anatolian Plateau, Turkey. Tectonics, 30:n/a- n/a. DOI: 10.1029/2010TC002756.

Yıldırım, C., Sarıkaya, M.A., Çiner, A. (2016). Late Pleistocene intraplate extension of the Central Anatolian Plateau, Turkey: Inferences from cosmogenic exposure dating of alluvial fan, landslide, and moraine surfaces along the Ecemiş Fault Zone. Tectonics, 35:1446-1464. DOI: 10.1002/2015TC004038.

Youssef, A.M., Pradhan, B., Al-Kathery, M., Bathrellos, G.D., Skilodimou, H.D. (2015). Assessment of rockfall hazard at Al-Noor Mountain, Makkah city (Saudi Arabia). using spatio- temporal remote sensing data and field investigation. $J$ African Earth Sci, 101:309-321. DOI: 10.1016/j.jafrearsci.2014.09.021.

Yusoff, A.R., Darwin, N., Majid, Z., Ariff, M.F.M., İdris, K.M. (2018). Comprehensive analysis of flying altitude for high resolution slope mapping using UAV technology. Int Arch Photogramm Remote Sens Spat Inf Sci, Vol XLII-3/W4, 2018 XLII:18-21.

Zeybek, M. Şanlığlu. (2014). Accurate determination of he Taşkent (Konya, Turkey). landslide using a long- range terrestrial laser scanner. Bull Eng Geol Environ, 74:61-76. DOI: 10.1007/s10064-0140592x.

Zorlu, K., Tunusluoglu, M.C., Gorum, T., Nefeslioğlu, H.A., Yalçın, A., Turer, D., Gökçeoğlu, C. (2011). Landform effect on rockfall and hazard mapping in Cappadocia (Turkey). Environ Earth Sci, 62:16851693. DOI: 10.1007/s12665-010-0653-9.

Zorlu, K., Türer, D., Tunusluoglu, M.C., Gökçeoğlu, C., Yalçın, A. (2008). Bir yerleşim yerinin (Yaprakhisar, Kapadokya). iki boyutlu kaya düşmesi analizleri ile kaya düşmesi riski açısından değerlendirilmesi. In: IX. Bölgesel Kaya Mekaniği Seтроzуити. İzmir, 361-372. 